\title{
О.М. Гнилко
}

\section{ПРО СЕДИМЕНТАЦІЙНІ ПРОЦЕСИ ФОРМУВАННЯ ФЛІШЕВИХ ВІДКЛАДІВ УКРАЇНСЬКИХ КАРПАТ}

\author{
O.M. Hnylko
}

\section{ON THE SEDIMENTARY PROCESSES OF THE FLYSCH DEPOSITS FORMING OF THE UKRAINIAN CARPATHIANS}

На основі седиментологічних досліджень у флішевих відкладах Українських Карпат були виділені літодинамічні типи, які відображають різні процеси формування осадів у глибоководних умовах. Флішеві утворення складені трьома групами літодинамічних типів: відкладами субвертикальних (“частинка за частинкою”) осадових потоків (геміпелагітами чи пелагітами); гравітитами (турбідитами з текстурами Боума, грейнітами, дебритами); контуритами.

Ключові слова: седиментаційні процеси, літодинамічні типи, флішеві відклади, Українські Карпати, турбідити, геміпелагіти, контурити.

\begin{abstract}
На основании седиментологических исследований во флишевых отложениях Украинских Карпат были выделены литодинамические типы, которые отображают различные процессы формирования осадков в глубоководных условиях. Флишевые образования сложены тремя группами литодинамических типов: отложениями субвертикальных («частичка за частичкой») осадочных потоков (гемипелагитами или пелагитами); гравититами (турбидитами с текстурами Боума, грейнитами, дебритами); контуритами.

Ключевые слова: седиментационные процессы, литодинамические типы, флишевые отложения, Украинские Карпаты, турбидиты, гемипелагиты, контуриты.
\end{abstract}

On the base of sedimentological investigations the lithodynamic types in the flysch deposits of the Ukrainian Carpathians were destinguished. These types represent the different sedimentary processes in the submarine conditions. Flysch deposits contain three groups of the lithodynamic types, namely, the deposits of the subvertical "particle by particle" sedimentary flow (hemipelagites or pelagites); gravitites (turbidites with Bouma's structure, the products of grain-flows and debris-flows); contourites.

Keywords: sedimentary processes, lithodynamic types, flysch deposits, Ukrainian Carpathians, turbidites, hemipelagites, contourites.

\section{ВСТУП}

Незважаючи на те, що терміну “фліш" понад 150 років, до цього часу генезис флішевих утворень викликав великі суперечки. Серед різних концепцій флішеутворення виділяються дві: осциляційна та "турбідитна". В основу осциляційної гіпотези, яку активно розробляв М.Б. Вассоєвич, покладено уявлення про дуже тісний зв'язок флішеутворення з періодичними коливаннями земної кори, в результаті яких виникає закономірне ритмічне перешаровування осадів. 3 позицій цієї гіпотези важко пояснити відсутність регресивної частини флішевого ритму, закономірність зміни характерних текстур у ритмі, що відносно легко пояснюються концепцією каламутних потоків. Один з авторів даної концепції Ф. Кюнен вважав, що осади, які нагромаджуються в області шельфу, внаслідок своєї ваги або під впливом сейсмічних поштовхів сповзають вниз і, змішуючись 3 морською водою, утворюють грандіозні турбідитні (каламутні, суспензійні) потоки, що переміщуються із швидкістю кур'єрського поїзда. 3 цих потоків, при сповільненні їх руху, випадають спочатку більш грубі, а пізніше - тонші осади.

Відповідно до сучасних уявлень [5, 7], флішеві відклади паралелізуються з осадами приконтинентальних океанічних областей (району материкового схилу та його підніжжя), які нагромадились внаслідок седиментаційних процесів, зумовлених, в основному, дією на осадові частинки або сил гравітації, або морських придонних течій. Ці процеси фіксуються певними різновидами осадів - літодинамічними (генетичними) типами відкладів (термін вживається в розумінні І. О. Мурдмаа [4]), які відрізняються між собою головним чином не речовинним складом, а текстурно-структурними ознаками.

Зауважимо, що поняття «літодинамічний тип» відрізняється від терміна "фація". Літодинамічний тип є продуктом тільки певного седиментаційного процесу, а фація - відображенням у породах осадової обстановки (різних, у тому числі палеогеографічних чи палеоокеаногра-

(C) О.М. Гнилко, 2010 
фічних умов середовища). Фація зазвичай складена певним комплексом літодинамічних типів відкладів. Так, фація глибоководного конуса виносу (фену) уламкового матеріалу, яку часто паралелізують з флішевими товщами, містить відклади різних літодинамічних типів - турбідитів, геміпелагітів, контуритів тощо. В той же час, наприклад турбідити, що вважаються найхарактернішим елементом флішу, трапляються в різноманітних фаціях.

В Українських Карпатах флішеві відклади досліджуються з актуалістичних позицій та порівнюються з осадовими утвореннями сучасних океанічних басейнів деякими дослідниками [1-3, 6 та ін.], проте 3 цього погляду системно не описані специфічні седиментологічні текстурно-структурні особливості флішу, які дають можливість визначати літодинамічні типи і розшифровувати давні седиментаційні процеси. Саме виділення та коротка характеристика літодинамічних типів деяких флішевих відкладів Українських Карпат і буде предметом нашого розгляду.

\section{МАТЕРІАЛ ТА МЕТОД}

Седиментологічні особливості порід охарактеризовані на основі дослідження автором у природних відслоненнях типових розрізів практично всіх структурних одиниць Українських Карпат. Роботи виконувались як самостійно, так і в ході геологічного довивчення території, що проводилось в 2001-2009 рр. спільно з геологами Львівської і Закарпатської експедицій при підготовці до видавництва Державних геологічних карт м-бу 1:200 000 Карпатської серії аркушів.

Розпізнавання літодинамічних типів відкладів проводилось за результатами аналізу текстурно-структурних рис порід та порівняння ï з описаними [4, 5, 7 та ін.] модельними діагностичними ознаками. Літодинамічні типи групувались відповідно до існуючої класифікації, що будується на основі типізації седиментаційних потоків, які їх породжують. За даними робіт [4, 5, 7 та ін.] можна виділити такі головні групи літодинамічних типів відкладів, що розвинені в позашельфових океанічних областях: відклади субвертикальних седиментаційних потоків; гравітаційні перевідкладені осади (гравітити); відклади придонних течій (контурити). Нижче розглянемо ці типи та їх представників у фліші Українських Карпат.

\section{ОБГОВОРЕННЯ РЕЗУЛЬТАТІВ}

Відклади субвертикальних седиментаційних потоків утворюють два головних, подібних між собою літодинамічних типи - пелагіти і геміпелагіти. Ці потоки діють постійно і формують універсальний "пелагічний фон" при нагромадженні інших різновидів осадів, зокрема при періодичному сходженні короткочасних катастрофічних турбідитних потоків. Пелагічні потоки в сучасних басейнах практично цілком біогенні, а геміпелагічні - включають деяку кількість теригенної чи едафогенної зависі, яка осаджується "частинка за частинкою" 3 водної товщі.

Типові пелагіти і геміпелагіти складені кременистими, вапнистими або теригенними мулистими утвореннями, що формують або самостійні товщі, або перешаровуються $з$ турбідитами, контуритами чи іншими літодинамічними типами. Їм притаманні або гомогенні текстури - за умови рівномірності седиментаційного потоку, або горизонтальна ламінація різного масштабу - при змінах інтенсивності потоку чи складу осадових частинок. Зауважимо, що пелагічна седиментація $€$ дуже повільною. При добрій аерації дна придонними збагаченими киснем течіями пелагічні осади часто збіднені органічною речовиною $\left(\mathrm{C}_{\text {орг }}\right)$ і забарвлені в червоний колір, оскільки органіка, що надходить на дно басейну, не перекривається новими порціями теригенного матеріалу і встигає повністю окиснюватись. Червоний колір зумовлений переходом заліза, яке міститься в осаді, в окисні форми. I навпаки, при поганій аерації дна пелагіти збагачуються органікою, яка не тільки не окиснюється, а і при повільній седиментації «не розбавляється" теригенним матеріалом. Такі відклади часто мають чорний колір.

В Українських Карпатах геміпелагіти, як правило, представлені паралельношаруватими аргілітами (рис. 1), іноді вапняками (рис. 2) чи силіцитами (рис. 3). Глинисті відклади цього типу з нижньокрейдового (спаська, шипотська світи) та олігоценового (менілітова світа) флішу, як правило, характеризуються чорним забарвленням та збагачені органічним матеріалом. Очевидно, в цей час у Карпатському флішевому басейні циркуляція придонних збагачених киснем вод була відсутня чи суттєво послаблена.

Значна частина геміпелагічних утворень в Карпатському фліші представлена червоними (іноді строкатими з прошарками зелених) аргілітами чи мергелями з тонкопаралельноламіно- 


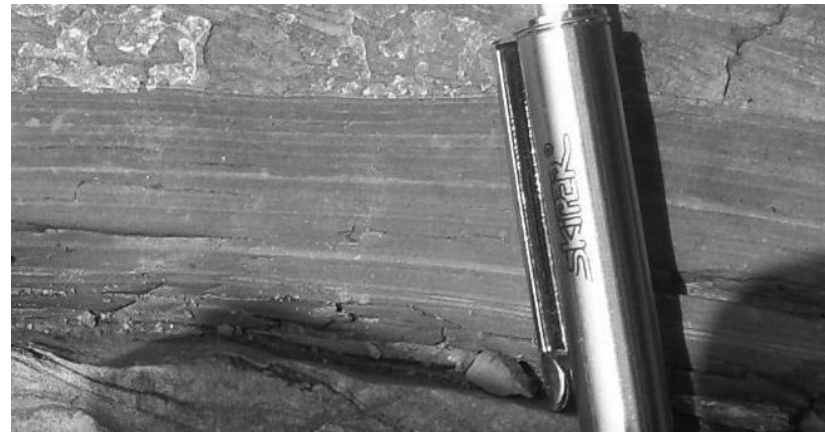

Рис. 1. Прошарок геміпелагітів - тонкопаралельноламінованих аргілітів. Темне забарвлення зумовлене збагаченням органічною речовиною. У світлих алевролітах вище і нижче геміпелагітів органіка "розбавлена" теригенним матеріалом. Олігоцен, кросненська світа, Сілезький покрив. Ріка Латориця, вище с. Підполоззя, Закарпатська область

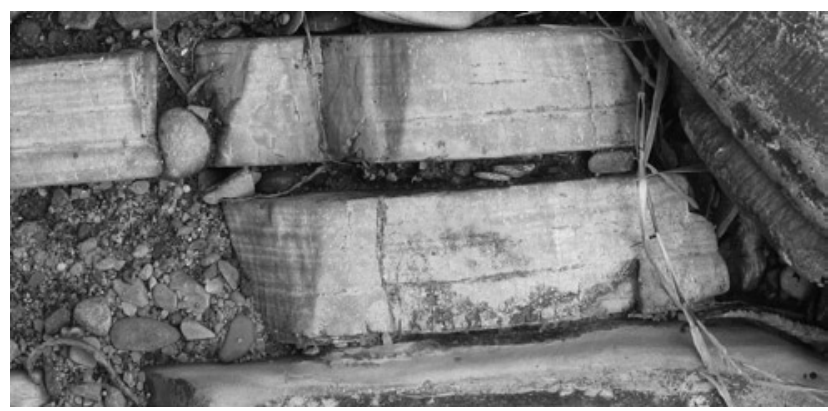

Рис. 2. Тонколаміновані "смугасті" вапняки (гемі) пелагічного походження. Головецький горизонтмаркер, кросненська світа, Сойменський субпокрив Сілезького покриву. Ріка Стрий, с. Мохнате, Турківський район, Львівська область

ваними чи гомогенними текстурами. До них відносяться верхньокрейдові (особливо туронські) та палеоцен-еоценові глинисті седименти. Червоний колір виник, вірогідно при добрій аерації дна збагаченими киснем течіями та "згоранні" органічної речовини. Відсутність органіки в глинах могла призвести до збереження окисних форм заліза в процесі діагенезу і утворення червоних аргілітів.

Гравітаційні перевідкладені осади (гравітити) включають підводно-осувні утворення та відклади гравітаційних потоків різною мірою розріджених мас осадів. Відклади потоків мас осадів поділяються на такі основні літодинамічні типи: турбідити, грейніти та дебрити.

Турбідити - продукти суспензійних гравітаційних потоків - найбільш поширений літодинамічний тип у приконтинентальних позашельфових океанічних областях. У ці потоки може бути залучений матеріал будь-якого складу і походження (кременистий, карбонатний, вулканогенний, біогенний, теригенний чи едафогенний

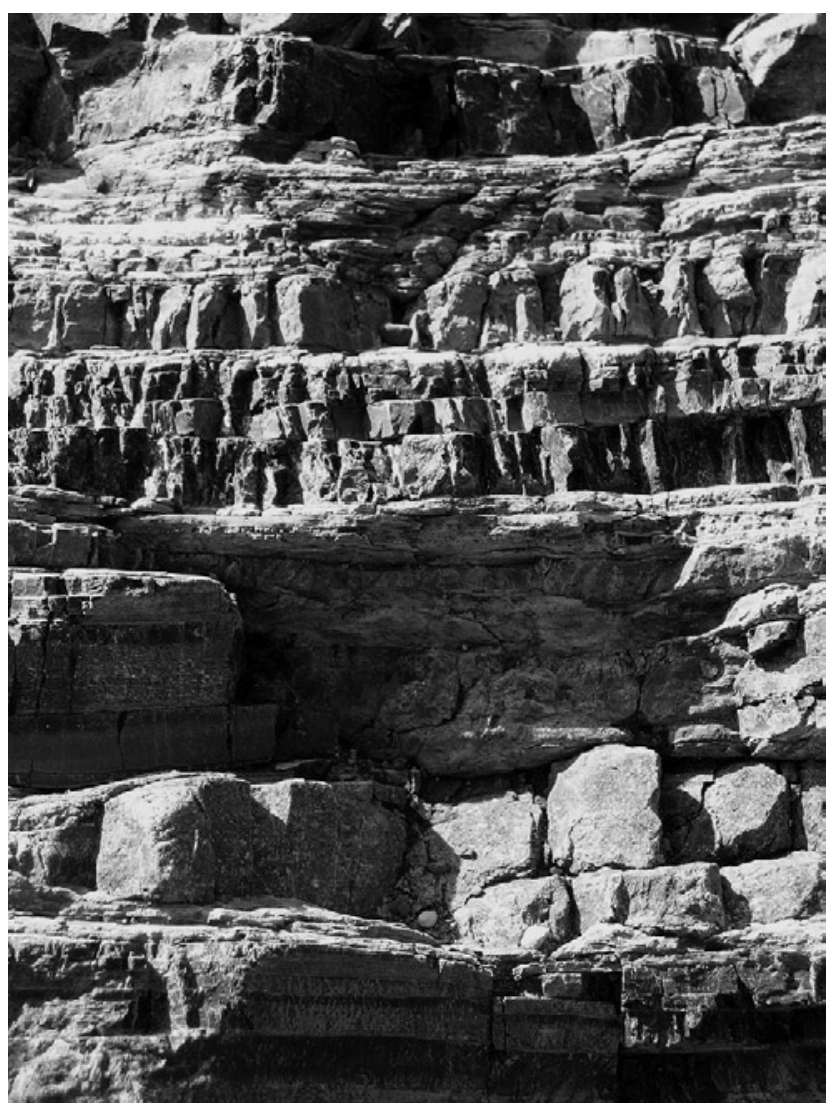

Рис. 3. Паралельношаруваті силіцити, кременисті алевроліти геміпелагічного походження. Нижній кременевий горизонт-маркер менілітової світи. Олігоцен, Скибовий покрив. Берег р. Опір, с. Верхнє Синьовидне, Львівська область

тощо). Виділяють [5] три основних різновиди турбідитів: грубо-, середньо- та дрібнозернисті.

Грубозернисті турбідити відкладені суспензійними потоками великої густини і складені грубоуламковими гравійно-гальковими відкладами і псамітами. Вони формують потужні (кілька метрів) пласти. Їм притаманні масивні, однорідні і пудингові текстури, іноді пряма й обернена градація уламкового матеріалу. В Українських Карпатах до них відносяться товщі товстошаруватого флішу типу нижньокросненської чи середньострийської підсвіт (рис. 4).

Середньозернисті турбідити характеризуються повною класичною послідовністю (циклом) текстурних елементів, які виділив А. Боума в 1960-х роках при вивченні третинного флішу на південному сході Франції. Ці елементи швидко були знайдені і в інших флішевих утвореннях, а також у сучасних осадах; в літературі вони зазвичай називаються "елементами чи інтервалами Боума». Повна їх послідовність включає таке: 


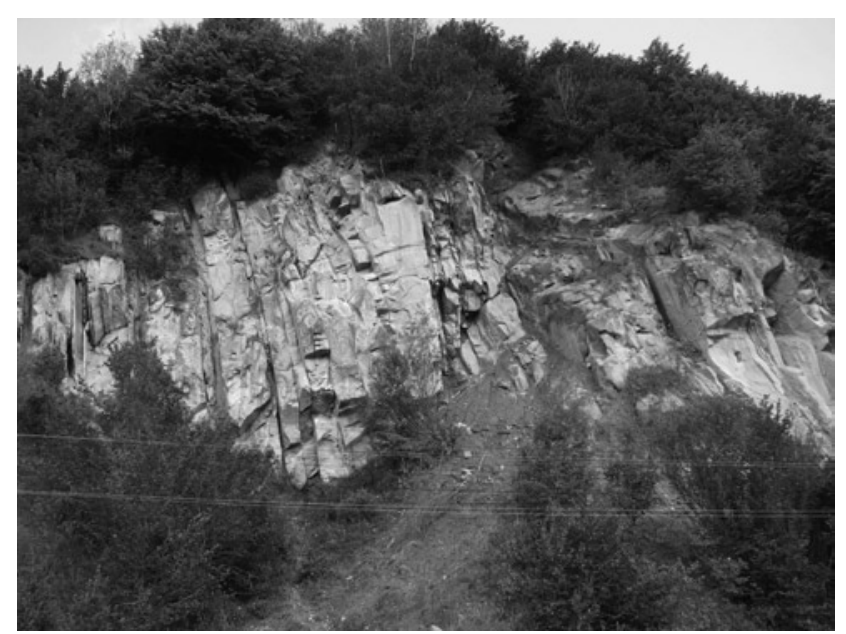

Рис. 4. Товстошаруватий фліш - грубозернисті турбідити та грейніти нижньокросненської підсвіти. Олігоцен. Місто Турка, Львівська область

$\mathrm{T}_{\mathrm{a}}$ - псамітовий інтервал з прямою градаційною шаруватістю, текстури гомогенні, масивні;

$\mathrm{T}_{\mathrm{b}}$ - нижній елемент з паралельною шаруватістю;

$\mathrm{T}_{c}$ - скісношаруватий інтервал брижі течії;

$\mathrm{T}_{\mathrm{d}}^{\mathrm{c}}$ - верхній паралельношаруватий інтервал;

$\mathrm{T}_{\mathrm{e}}$ - пелітовий гомогенний елемент.

Вважається, що описаний модельний пласт відкладається з одного турбідитного потоку, що поступово слабшає. В природніх розрізах з цієї послідовності часто випадають нижні чи верхні елементи.

Подібні відклади суспензійних потоків є дуже поширеними у Карпатському фліші, де трапляються середньозернисті "класичні" турбідити 3 повним набором текстурних елементів циклу Боума типу $T_{\text {abcde }}$ (рис. 5). Вони, по суті, складають основну частину товщ середньоритмічного флішу Карпат, хоча текстури Боума в них бувають неповні (рис. 6) або не чітко виражені.

Дрібнозернисті турбідити відкладені каламутними потоками порівняно невеликої густини і характеризуються текстурними елементами Боума типу $T_{\text {cde }}$ та $T_{\text {de }}$. Більша частина тонкоритмічного флішу Українських Карпат складена саме цими турбідитами (рис. 6).

Середньо- та дрібнозернисті турбідити часто добре поширені по латералі, хоча іноді і заповнюють палеорусла (рис. 7). Їм нерідко притаманні відбитки слідів суспензійних потоків (рис. 8).

Грейніти - до них ми в даній роботі відносимо відклади потоків розріджених зернистих осадів (піску, алевропсаміту), незалежно від способу

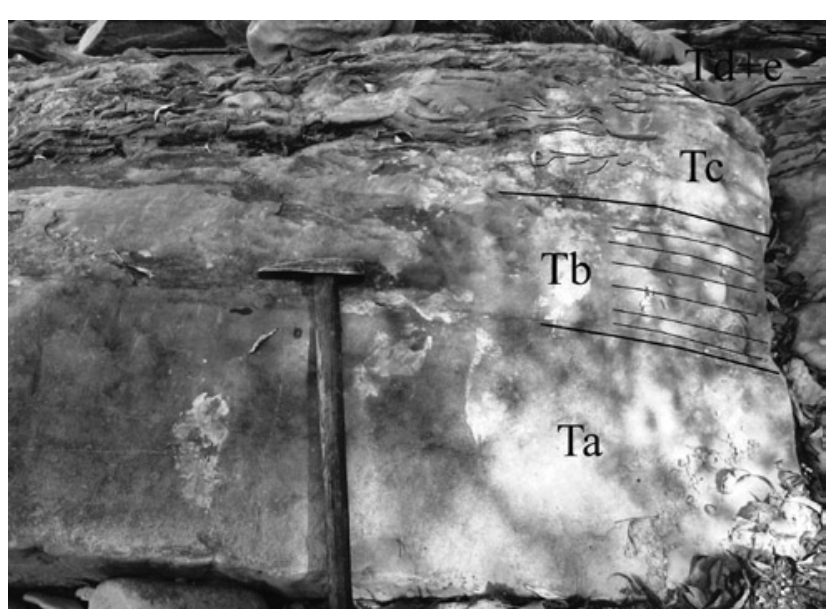

Рис. 5. Середньозернистий турбідит з повною «класичною" послідовністю елементів Боума $\mathrm{T}_{\text {abcde }}$ Олігоцен, кросненська світа. Лівий берег р. Стрий, с. Верхнє Висоцьке, Львівська область

утримання частинок у потоці. Ці зернові потоки (англ. grain-flow) можуть діяти або самостійно, або супроводжувати нижню частину потужних високогустинних турбідитних потоків (рис. 4). Для грейнітів не є характерними градаційна чи скісна верствуватість; вони, як правило, виражені масивними пластами псамітів з різкими верхніми і нижніми контактами. В пластах часто "розсіяні" гравійно-галькові уламки (пудингова текстура). Подібні пласти часто трапляються в товсторитмічному фліші Українських Карпат (рис. 4, 9).

Дебрити - це відклади грязьокам'яних чи мулисто-уламкових (англ. debris-flow) потоків, які переміщуються під дією гравітації вниз по підводних схилах у вигляді розрідженої суміші грубоуламкового і тонкозернистого матеріа-

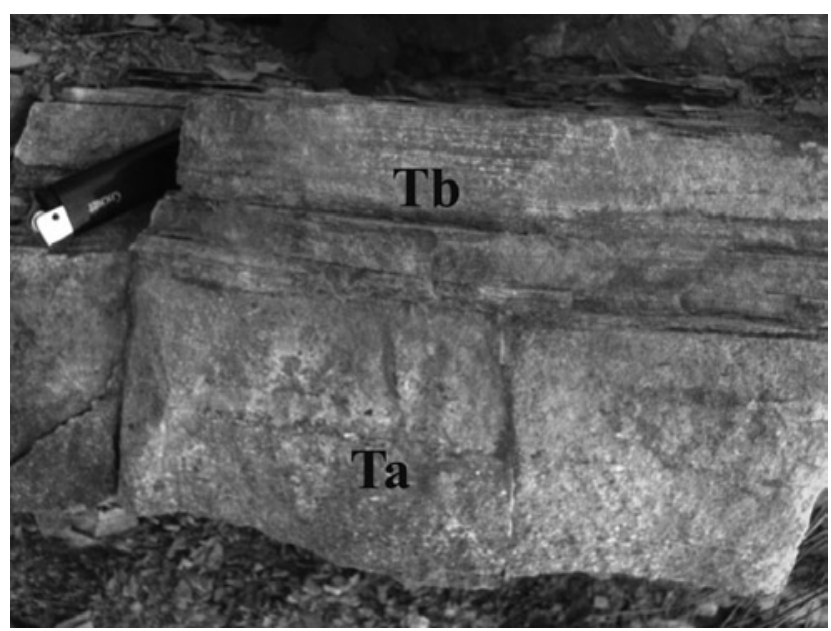

Рис. 6. Турбідит з неповним набором текстур Боума $\mathrm{T}_{\mathrm{ab}}$. Стрийська світа, сенон-палеоцен, БориславськоПокутський покрив. Ріка Черемош, м. Кути, ІваноФранківська область 


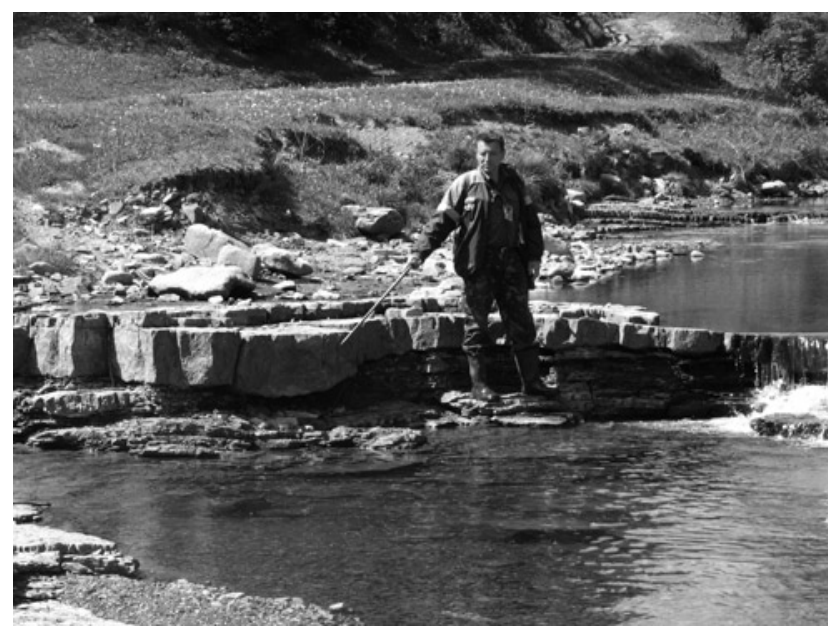

Рис. 7. Тонкоритмічний, місцями середньоритмічний фліш бистрицької світи - чергування геміпелагітів (тонколамінованих зелених аргілітів) та тонко-середньошаруватих турбідитів 3 текстурами типу $\mathrm{T}_{\text {abcde' }} \mathrm{T}_{\text {cde }}$ (дрібнозернисті пісковики та алевропеліти). Потовщення турбідитного пласта в області давнього підводного русла-каналу. Скольська скиба. Права притока р. Опір - р. Кам'янка, біля м. Сколе, Львівська область

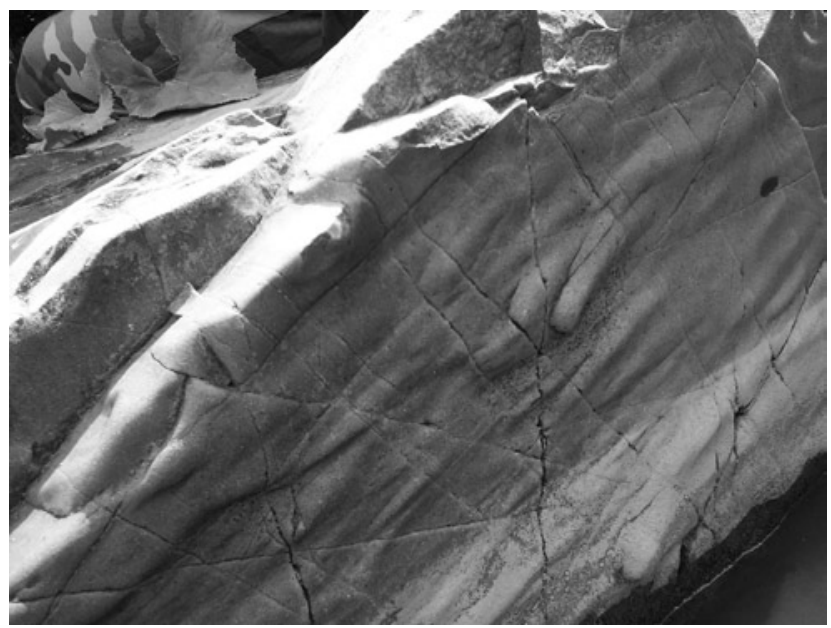

Рис. 8. Відбитки слідів палеотечій на нижній поверхні турбідитного пласта. Кросненська світа, олігоцен, Сілезький покрив. Ріка Латориця, с. Підполоззя, Закарпатська область

лу (подібно до селевих потоків). У дебритах, як правило, відсутні сортування матеріалу та шаруватість; вони характеризуються пудинговою текстурою - включеннями розсіяних уламків різного розмірув тонкозернистомуматриксі.Дебрисні потоки супроводжують підводно-осувні явища, сукупність яких, по суті, утворюють олістостроми. Лінзи дебритів різної потужності широко розвинені серед шаруватого флішу Карпат і здебільшого складають матрикс олістостромових товщ (рис. 10).

Відклади придонних течій, як правило, присутні у фліші, формуючи окремі шари та пачки. B

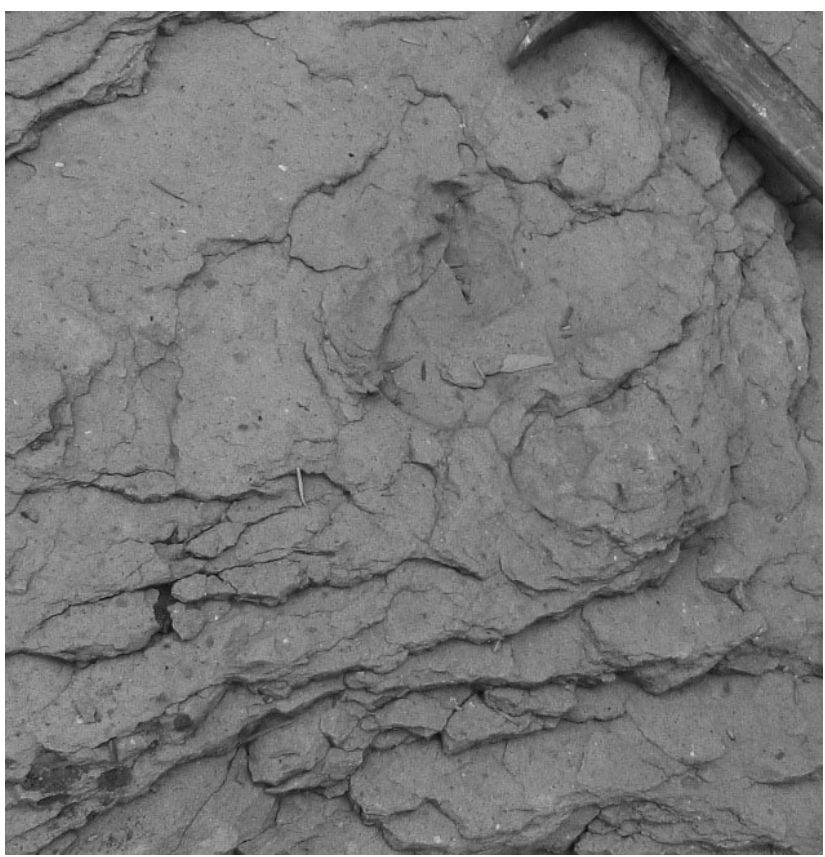

Рис. 9. Грейніт - продукт зернового потоку. Текстура масивна, пудингова з уламками перевідкладеного флішу. Кросненська світа, Сілезький покрив. Правий берег ріки Стрий, нижче м. Турка, Львівська область

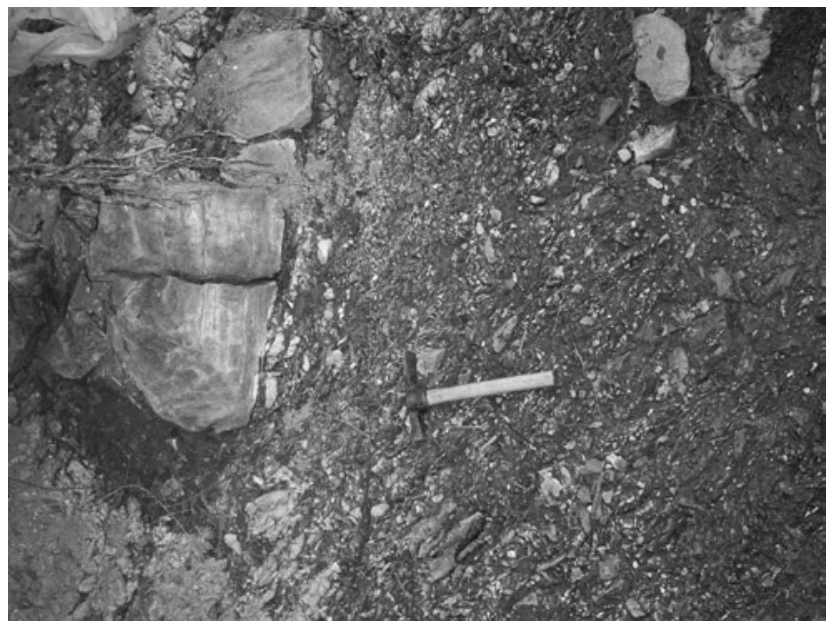

Рис. 10. Відклади грязьокам'яного потоку - дебрити. Волосянківська олістострома (лежить на кросненській світі). Брили порід кросненського флішу. Олігоцен. Сілезький покрив. Берег р. Латориця, с. Підполоззя, Закарпатська область

літературі вони іноді мають назву "контурити", оскільки в основному формуються течіями, що огинають контури континентальних масивів. Окремі пласти контуритів найчастіше складені добре відсортованими скісношаруватими алевропсамітами та дрібнозернистими псамітами, що мають чіткі нижні та верхні обмеження. В цих відкладах іноді спостерігається так звана флазерна та лінзоподібна верствуватість лінзочки глинистого матеріалу в алевропсамі- 


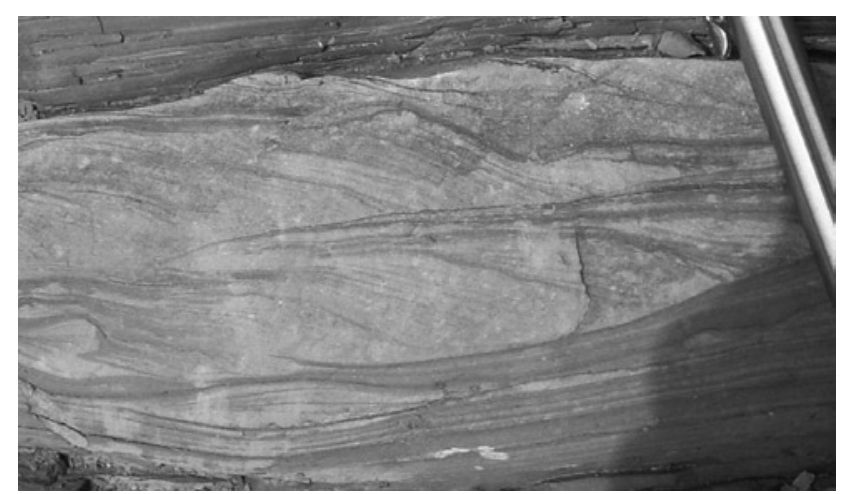

Рис. 11. Відклади придонних течій. На верхній поверхні пластів скісношаруваті текстури ерозійно зрізаються, а на нижній - характеризуються формами прилягання. За цією ознакою визначається перевернене залягання. Кросненська світа, олігоцен, Сілезький покрив. Ріка Латориця, с. Підполоззя, Закарпатська область

тах. Глинистий матеріал нагромаджується в улоговинках між окремими псамітовими валиками брижі течії у фазу спокою (ослаблення течії), а у фазу активної течії - перекривається піском.

Шари і пачки, складені відкладами течій, приурочені до різних відмін Карпатського флішу. Їм притаманні скісношаруваті текстури, які охоплюють увесь розріз осадових шарів; елементи Боума відсутні (рис. 11). Слід зауважити, що іноді важко визначити, чи то скісношаруваті седименти відносяться до відкладів течій, чи то - до дистальних турбідитів з текстурами типу $\mathrm{T}_{\text {cde }}$

Наші спостереження показують, що відклади субгоризонтальних седиментаційних потоків (фонові геміпалагічні осаджені "частинка за частинкою"), а також грязьокам'яних потоків та придонних течій характерні не тільки для флішевих, а і для інших осадових утворень, наприклад для молас. Водночас турбідити є характерними саме для флішу; по суті, більша частина флішевої формації складена турбідитами, що ритмічно перешаровуються з геміпелагітами (рис. 12).

\section{ВИСНОВКИ}

Проведене автором вивчення розрізів осадових порід дозволяє констатувати, що давні седиментаційні процеси призвели до формування декількох літодинамічних (генетичних) типів флішевих відкладів. Седиментологічні текстурно-структурні ознаки свідчать, що крейдово-міоценові флішеві утворення Українських Карпат складені трьома головними групами літодинамічних типів відкладів позашельфових океанічних областей: літифікованими осадами субвертикальних геміпелагічних пото-

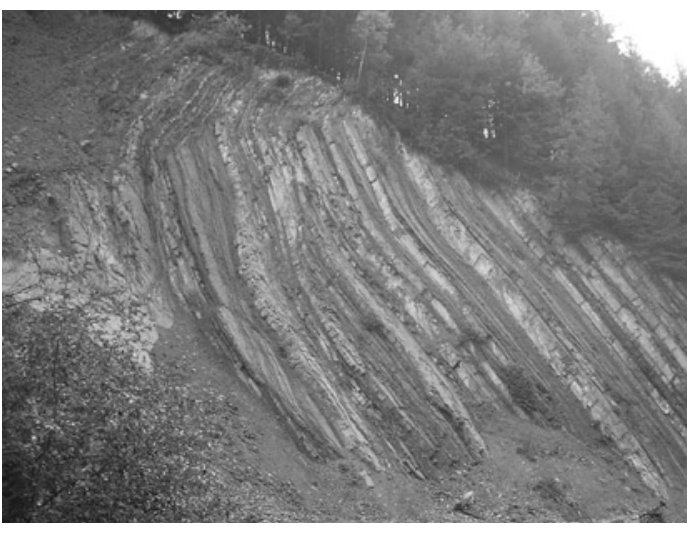

Рис. 12. Типове для флішу ритмічне чергування середньозернистих турбідитів (світло-сірих алевропсамітових пластів) та геміпелагітів (темно-зелених верств аргілітів). Еоцен, Скибовий покрив. Ріка Головчанка, Сколівський район, Львівська область

ків типу "частинка за частинкою»; гравітитами; відкладами придонних течій. Серед гравітитів розрізняються турбідити - результати діяльності каламутних суспензійних потоків різної густини, грейніти та дебрити - продукти відповідно зернових (англ. grain-flow) та грязьокам'яних (мулисто-уламкових, англ. debris-flow) потоків. Ці три групи чергуються між собою в розрізах флішу. Більша частина флішевої формації складена геміпелагітами та турбідитами, що ритмічно перешаровуються.

1. Геологічна палеоокеанографія океану Тетіс / Ю. Сеньковський, К. Григорчук, В. Гнідець, Ю. Колтун. - К.: Наук. думка, 2004. - 172 с.

2. Гнилко С., Гнилко О. Ранньоеоценові аглютиновані форамініфери і седиментологічні особливості формування флішу Монастирецького та Скибового покривів Українських Карпат // Геологія і геохімія горючих копалин. - 2010. - № 1(150). - С. 43-59.

3. Иваник М.М., Маслун Н.В. Кремнистые микроорганизмы и их использование для расчленения палеогеновых отложений Предкарпатья. - Киев: Наук. думка, 1977. - 118 с.

4. Мурдмаа И.О. Фации океанов. - М. : Наука, 1987. $303 \mathrm{c}$.

5. Обстановки осадконакопления и фации. В 2-х т. Пер. с англ.; - Т. 2. Под. ред. Х. Рединга. - М.: Мир, 1990. $-384 \mathrm{c}$.

6. Пилипчук А. С., Рейфман Л. М. О принципах выделения литофаций в Карпатском флише // Геология Советских Карпат. - Киев: Наук. думка, 1989. - С. 156-162.

7. Einsele G. Sedimentary Basins: evolution, facies and sediment budget. - Berlin: Springer — Verlag, 1992. $615 \mathrm{p}$.

Інститут геології і геохімії горючих копалин НАН України, Львів

E-mail: igggk@mail.Iviv.ua; gnylko_o@mail.ru

Рецензент - чл.-кор. НАН України М.І. Павлюк 